\title{
A PROBLEM OF SCIENCE LITERACY ENCOUNTERED BY PRIMARY SCHOOL TEACHERS AND LEARNERS
}

\author{
Vincentas Lamanauskas \\ University of Siauliai, Siauliai, Lithuania
}

\begin{abstract}
Science education is one of the key areas of general education in comprehensive school (Lamanauskas, 2009). The major argument for defining the relevancy of the introduced subject is the universality and integrity of science education. For the last two decades, particularly this field of education has faced a number of different changes in the majority of countries: variations in the content of education, search for efficient forms and methods of teaching, innovative approaches, etc. are only a few questions that must be properly discussed. On the other hand, needs for the quality of provided services necessary for modern society are emphasized. The present community finds knowledge of science and ability to apply the acquired information in practice as the main priorities. The fields of exploitation of natural recourses and nature protection as well as the problems of ecology, biotechnology, genetically modified organisms, etc. have become everyday reality, i.e. the relationship between human and nature has grown into a complex and controversial process as never before, whereas human interests often oppose nature. The formation of responsibility for an impact on nature frequently accepts sciences as the core area of the educational process. However, this is totally impossible ignoring the nature and natural laws of evolution. Knowledge of nature is crucial, particularly at the young age. The main emphasis on education in primary school, in general, should be placed on assistance for schoolchildren to achieve a certain level of competencies such as moral values, knowledge, abilities. To acquire and develop skills, yet in primary school, the learners should observe, research and conduct experiments on both animate and inanimate nature. R. Makarskaitè makes a remark that'research helps with acknowledging variety in animate nature and establishing relationships with inanimate nature as every component of the environment plays an important role. This is how an attitude towards nature protection and responsibility for the destiny of nature are formed' (Makarskaite, 1996). Observations, experiments and research are efficient activities and help the children with a correct understanding of natural processes, human adaptation to the processes taking place in nature, perceiving troubled relationships between human and nature, etc. The information obtained in primary school should assist the learners in applying the method of scientific research observing and analysing phenomena emerging in nature, developing the ability to collect and use data, knowing the ways to admit natural facts and phenomena, employ schemes, tables, diagrams, etc. and demonstrating skills at predicting the sequence of the actions taken, including the necessity for making corrections. To increase the level of science literacy, the students should know how to effectively combine methods and techniques for nature acquisition.

In this case, a more detailed discussion that science literacy achieved in primary school causes problems in the majority of countries is not required. For example, according to the results of the conducted international research PISA (Programme for International Student Assessment) focusing on the abilities of 15 year old students to deal with reading, math and science tasks, the results achieved by Lithuanian representatives are slightly lower than the international average (http://www.smm.lt/svietimo_bukle/ docs/pr_analize/SPA(6)_Penkiolikmeciu_rastingumas.pdf). An idea that these results have been directly determined by the situation of science education in primary school cannot be accepted. On the other hand, we cannot completely agree that science education acquired in primary school will have no impact on the students' achievements at other stages of the educational process.
\end{abstract}


To achieve an adequate level of science literacy in primary school, the questions addressed to the education of science teachers must be seriously considered. If the main teacher's activity focused on gaining information about nature is based on interpretation and reading books, then, this activity will reflect a traditional educational methodology; in this case, the students will operate only theoretical knowledge and will frequently fail to understand processes taking part in nature, i.e. in general, they will not be engaged in sciences at higher levels of comprehensive school. Optimal results can only be achieved it the teacher him/herself really likes his/her job, is constantly involved in research activities, encourages and helps children with a deeper understanding of nature and is particularly interested in the problems of sciences. An important point is that primary school builds foundations for science education the quality of which will have a powerful impact on further education of the young generation.

Thus, to meet the needs of all students and society, in terms of science education (competencies), the system of training/preparing science teachers, particularly that of primary school teachers (educational curricula, organization and content of pedagogical practice, etc.), must be upgraded. The evaluation of a number of parameters discloses that the science literacy of primary school teachers is not sufficient (for example, teachers frequently avoid trips to nature because have a poor knowledge of local natural area, have no skills at using special instruments, etc.). A primary school teacher must have enough knowledge and abilities of physics, chemistry, engineering and technology, ecology, etc. Systemic integral science preparation also plays a crucial role for primary school teachers. Nevertheless, obviously, only cosmetic changes in training teachers will not be effective. Researchers representing several countries notice a lack of motivation in primary school and call this phenomenon "crisis" (Wang, 2004; Bennell, Mukyanuzi, 2005; Bhatti, Rawat, Hamid, 2012). This is common not only to developing but also to the developed and economically-strong countries. In this particular case, the motivation of primary school teachers for pedagogical activities is generally taken into account. Discussions on science education show this problem particularly burning, because, traditionally, primary school teachers are not adequately prepared for teaching science and technology topics at an appropriate level. To deal with this question, withdrawal or avoidance are most frequently chosen. Attention is paid to social education. Some researchers accept (Goodwin, Orlik, 2012) it is vital that the teacher should be personally interested in the subject to be taught. Only the teacher able to develop students' ingenuity and creativity, encourage their curiosity and initiative and stimulate exploration, search and discovery can expect for good results of science education.

\section{References}

Bennell, P., Mukyanuzi, F. (2005). Is There a Teacher Motivation Crisis in Tanzania? Brighton: Knowledge and Skills for Development.

Goodwin, A., Orlik, Y. (2012). Communicating Science: between people, countries and cultures. Journal of Science Education, $13(1), 3$.

Lamanauskas, V. (2009). Gamtamokslinio ugdymo stiprinimo svarba ir būtinumas pradineje mokykloje. Gamtamokslinis ugdymas / Natural Science Education, Nr. 1 (24), p. 4-7.

Makarskaitè R. (1996). Aplinkotyrinès Vinco Ruzgo idejjos ir šiuolaikinė mokykla. Kn. Gamtamokslinis ugdymas pagrindineje bendrojo lavinimo mokykloje. Vilnius.

Wang, H. (2004). Why teach science? Graduate science students' perceived motivations for choosing teaching as a career in Taiwan. International Journal of Science Education, 26 (1), 113-128.

Bhatti, T., Rawat, K. J., Hamid, S. (2012). Motivation Crisis among Primary School Teachers: A Descriptive Study. American Journal of Scientific Research, 51, 122-131.

Received: October 15, 2012

Accepted: November 25, 2012

\begin{tabular}{|rl|}
\hline Vincentas & PhD, (HP), Professor, Natural Science Education Research Centre, \\
Lamanauskas & University of Siauliai, 25-119 P. Vi inskio Street, LT- 76351, Siauliai, \\
& Lithuania. \\
& E-mail: lamanauskas@lamanauskas.puslapiai.It \\
& Website: http://www.lamanauskas.puslapiai.It/ \\
\hline
\end{tabular}

